E3S Web of Conferences 1, 16008 (2013)

DOI: $10.1051 / \mathrm{e} 3$ sconf/20130116008

(c) Owned by the authors, published by EDP Sciences, 2013

\title{
Human impact on fluvial sediments: how to distinguish regional and local sources of heavy metals contamination
}

\author{
T. Novakova ${ }^{1,3}$, T. Matys Grygar ${ }^{1}$, O. Babek ${ }^{2}$, M. Famera ${ }^{2}$, M. Mihaljevic $^{3}$ and L. Strnad ${ }^{3}$ \\ ${ }^{1}$ Institute of Inorganic Chemistry AS CR, v.v.i., 25068 Řež, Czech Republic, faramira@centrum.cz \\ 2 Department of Geology, Palacký University, Tř. Svobody 26, 77146 Olomouc, Czech Republic, \\ babek@prnfw.upol.cz,mafam@post.cz \\ ${ }^{3}$ Charles University, Faculty of Science, Albertov 6, 12843 Prague, Czech Republic, mihal@natur.cuni.cz, \\ lada@natur.cuni.cz
}

\begin{abstract}
Regional contamination of southern Moravia (SE part of the Czech Republic) by heavy metals and magnetic particles during the 20th century was quantified in fluvial sediments of the Morava River. The influence of local sources to the regional contamination of the river sediments and impact of sampling sites heterogeneity were studied in profiles with different sedimentology (facies) and lithology. For this purpose, hundreds of samples were obtained from regulated channel banks and naturally inundated floodplains and proxy elementary analyses have been carried out by X-ray fluorescence spectroscopy (ED XRF), further calibrated by ICP MS. Magnetic susceptibility as a proxy of industrial contamination was determined and the age model has been obtained by ${ }^{210} \mathrm{~Pb}$ dating method. After establishing the lithological background from floodplain profiles, assessment of heavy metal contamination was done by using enrichment factors (EFs) of heavy metals $(\mathrm{Pb}, \mathrm{Zn}, \mathrm{Cu}, \mathrm{Cr})$ and magnetic susceptibility. Floodplain sedimentary profiles were found to be realiable for assessment of contamination and reconstruction of large scale, i.e. a really averaged regional contamination, while regulated channel banks are suitable for obtaining of more or less qualitative information of influence of local point sources in the area because sediments from regulated river banks qualitatively reflect the actual local contamination of the river system. It allowed us to distinguish the influence of local sources of contamination by comparing with more spatially averaged contamination signal from more distal floodplain profiles. The study area is rather weakly contaminated (EF 1-2), while individual sediment strata from regulated channel banks contains several times larger concentrations of heavy metals.
\end{abstract}

Key words: Heavy metals, enrichment factors, normalization, fluvial sediments; local sources, regional contamination

\section{Introduction}

Industrial pollution can provide a very useful tool to study spatiotemporal distribution of heavy metlas in modern floodplain sediments, could allow us to trace their provenance, and datingof sedimentary profiles. There is no universal method for assessment of regional contamination (Rubio et al., 2000) in industrialy contaminated areas and also in non-industrial areas and the aim of this work was to answer following questions: what sampling sites, profiles and methodologies have to be used for assessment of contamination in non-industrial area and what is the influence of local points source (industry in Zlín area) with respect to the regional contamination. Contamination of southern Moravia (SE of the Czech Republic, Fig. 1) by heavy metals during the 20th century was determined in fluvial sediments of the Morava River by means of enrichment factors (Covelli and Fontolan, 1997) and the influence of local sources and sampling sites heterogeneity were studied in overbank fines with different lithology and facies.

\section{Materials and Methods}

Sedimentary samples were obtained from near naturally inundated floodplains in two nature protected areas (at 30 $\mathrm{km}$ distance) and from the regulated channel banks, with 
well-defined local sources of contamination (factories in Zlín and Otrokovice) (Fig.1).
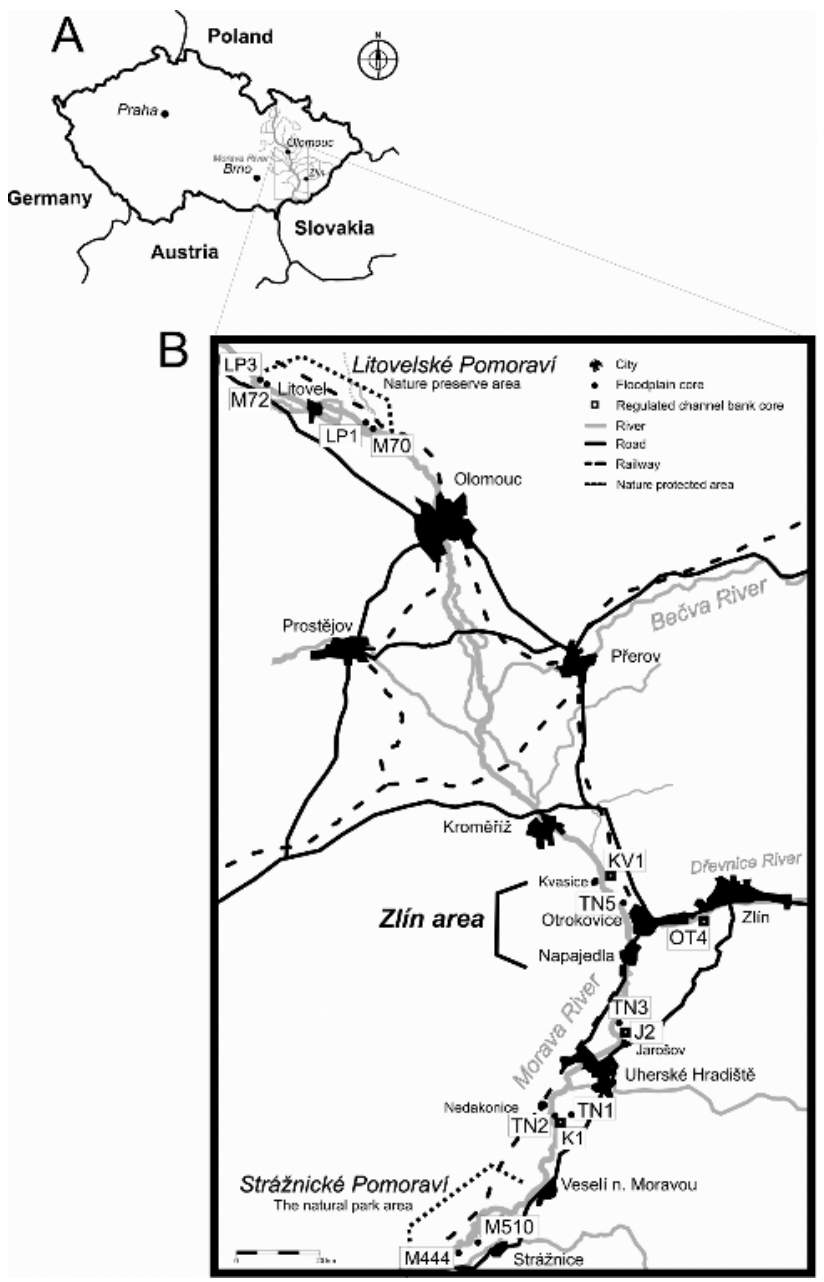

Fig. 1. Study area with the local source of contamination from industrial enterprises in Zlín area

Geochemical analytical proxy methods such as elementary analysis using X-ray fluorescence spectroscopy (ED XRF), cationt exchange capacity (CEC) (as a proxy of expandable clay minerals content), measurement of magnetic susceptibility (a proxy of heavy metals concentrations) and ${ }^{206} \mathrm{~Pb} /{ }^{207} \mathrm{~Pb}$ isotopic ratio were used. Selected sedimentary samples were analysed also by ICP MS and results were used for calibration of ED $\mathrm{XRF}$ results. ${ }^{210} \mathrm{~Pb}$ activities were used for dating of profiles.

\section{Resuts and Discussion}

Enrichment factors (EF) of heavy metals ( $\mathrm{Pb}, \mathrm{Zn}, \mathrm{Cu}$ and $\mathrm{Cr}$ ) and magnetic susceptibility of overbank fines in near-naturally (near annually) inundated areas allowed us to reconstruct historical contamination by heavy metals in the entire study area independently on lithofacies.

In the case of floodplain sediments, basic description of the floodplain structure and facial analysis are essential. It is of crucial importance for the evaluation of possible post-depositional migration of pollutants in sedimentary profiles and determination of the lithogenic background (geochemical baseline). Lithogenic background values should be calculated from relevant parts of sedimentary profiles with guaranteed vertical stability of the pollutants, lithologically uniform with the top, polluted strata, and without signs of reductimorphic processes (Grygar et al., 2010; Matys Grygar et al., 2011, Matys Grygar et al. 2012). Calculated lithological background values were then used for calculation of EFs in the channel sediments and in nearly naturally inundated floodplain sedimentary profiles.

The profiles from regulated river reaches are highly prone to local sources and due to the stratigraphic chaos and post-depositional mobilization of heavy metals, which we revealed using ${ }^{206} \mathrm{~Pb} /{ }^{207} \mathrm{~Pb}$ ratio; such profiles were further excluded from an evaluation of regional contamination. Overbank fines in the study area (middle and lower reach of the Morava) are only weakly but whole-regionally contaminated (maximal EFs are 1.3-2 for $\mathrm{Pb}$ and $\mathrm{Zn}, 1.2-1.7$ for $\mathrm{Cu}, 1.1-1.2$ for $\mathrm{Cr}$ and 2-4 for magnetic susceptibility). Regulated river channel sediments, which reflect the actual contamination from local sources, produced apparent EFs ranging from 0.3 to 15 for heavy metals and 0.4-21 for MS, with the highest values obtained downstream from the most relevant point source in the study area, shoe-making and related chemical industry in Zlín and Otrokovice (Fig 2).

\section{Conclusion}

Overbank fines in the study area (middle and lower reach of the Morava) are only weakly but whole-regionally contaminated. Sediments from regulated channel banks were found stratigraphically and lithologically "erratic", unreliable for quantification of regional contamination due to a high variability of sedimentary environment. On the other hand, these sediments are very sensitive to the nearby local sources of heavy metals.

For a practical work, one must first choose whether large scale, i.e. a really averaged regional contamination should be reconstructed, or whether more or less qualitative information on local point sources is searched for.

\section{Acknowledgements}

The fieldworks in the Morava River watershed and also ${ }^{210} \mathrm{~Pb}$, ICP MS, ED XRF and MS analyses were funded by GA UK project 46210 . Works related to the profiles from riverbanks near Otrokovice were provided thanks to MSM0021622412 (INCHEMBIOL). The fieldworks in Strážnické Pomoraví area were funded by IAAX00130801 (Grant Agency of AS CR) and ED XRF analyses of samples from Strážnické Pomoraví area were provided thanks to research project AV0Z40320502 at the Institute of Inorganic Chemistry AS CR, Rez, where also many hundreds of samples have been processed in analytical laboratory by J. Dörflová, Z. Hájková, and P. Vorm. 

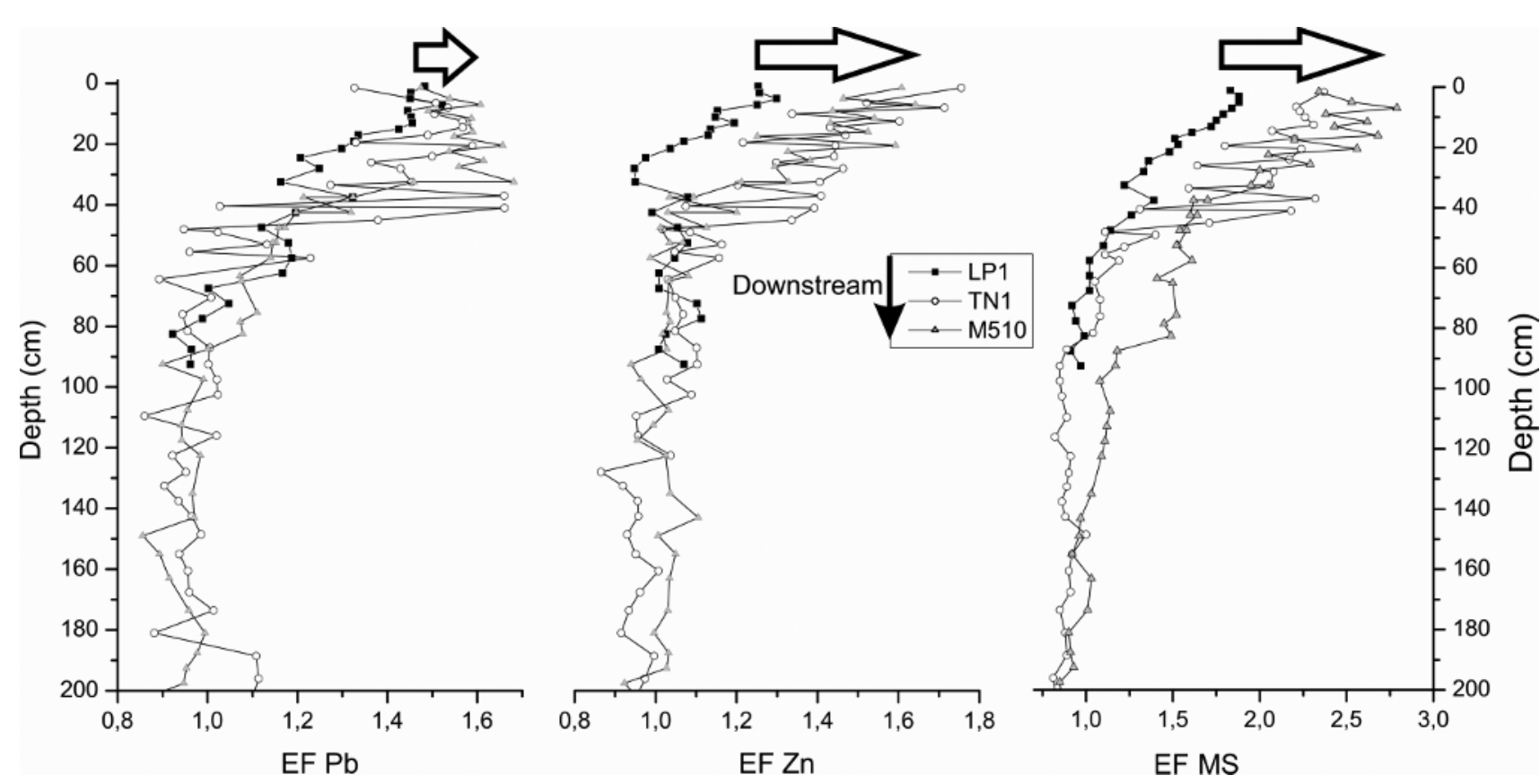

Fig. 2. Downstream regional development of $\mathrm{Pb}, \mathrm{Zn}$ and $\mathrm{MS}$ enrichment factors with significant influence of local point source

\section{References}

Covelli, S., Fontolan, G.. Application of a normalization procedure in determining regional geochemical baselines: Gulf of Trieste, Italy. Environ. Geol. 1997; 30: 34-45.

Grygar, T., Světlík, I., Lisá, L., Koptíková, L., Bajer, A., Wray, D.S., Ettler, V., Mihaljevič, M., Nováková, T., Koubová, M., Novák, J., Máčka, Z., Smetana, M. Geochemical tools for the stratigraphic correlation of floodplain deposits of the Morava River in Strážnické Pomoraví, Czech Republic from the last millennium. Catena 2010; 80: 106-121.

Matys Grygar, T., Nováková, T., Mihaljevič, M., Strnad, L., Světlík, I., Koptíková, L., Lisá, L., Brázdil, R.,
Máčka, Z., Stachoň, Z., Svitavská-Svobodová, H., Wray, D.S. Surprisingly small increase of the sedimentation rate in the floodplain of Morava River in the Straznice area, Czech Republic, in the last 1300 years. Catena 2011; 86:192-207.

Matys Grygar, T., Sedláček, J., Bábek, O., Nováková, T., Strnad, L., Mihaljevič, M. Regional contamination of Moravia (south-eastern Czech Republic): Temporal shift of $\mathrm{Pb}$ and $\mathrm{Zn}$ loading in fluvial sediments. Water, Air and Soil Pollution 2012; 223: 739-753.

Rubio, B., Nombela, M. A., Vilas, F. Geochemistry of major and trace elements in sediments of the Ria de Vigo (NW Spain). Marine pollution Bulletin 2000; 40: $968-980$. 